\title{
野生動物の感染症管理にどのように取り組むべきか
}

\author{
高見一利 ${ }^{1)}$, 渡邊有希子 ${ }^{2)}$, 坪田敏男 ${ }^{3)}$, 福井大祐 ${ }^{4)}$, 大沼 ${ }^{\text {学 }}{ }^{5)}$, 山本麻衣 ${ }^{6)}$, 村田浩一 ${ }^{7)}$ \\ 1）大阪市天王寺動植物公園事務所干５43-0063 大阪市天王寺区茶臼山町 1-108 \\ 2）猛禽類医学研究所 $\overline{0} 084-0922$ 北海道釧路市北斗 $2-2101$ \\ 3）北海道大学大学院獣医学研究科 $=060-0818$ 札幌市北区北 18 条西 9 丁目 \\ 4）旭川市旭山動物園％ 078-8205 旭川市東旭川町倉沼 \\ 5）独立行政法人国立環境研究所％ 305-8506 茨城県つくば市小野川16-2 \\ 6）環境省自然環境局鳥獣保護業務室％100-8975＼cjkstart東京都千代田区霞が関 1-2-2 \\ 7）日本大学生物資源科学部干252-0880 神奈川県藤沢市亀井野 1866
}

\section{How to Tackle The Management of Infectious Diseases in Wild Animals}

\author{
Kazutoshi TAKAMI $^{1)}$, Yukiko WATANABE ${ }^{2)}$, Toshio TSUBOTA ${ }^{3)}$, Daisuke FUKUI ${ }^{4)}$, Manabu ONUMA ${ }^{5)}$, \\ Mai YAMAMOTO ${ }^{6)}$ and Koichi MURATA ${ }^{7)}$ \\ 1) Osaka Municipal Tennoji Zoological Gardens, Osaka 543-0063, Japan \\ 2) Institute for Raptor Biomedicine Japan, Kushiro, Hokkaido 084-0922, Japan \\ 3) Graduate School of Veterinary Medicine, Hokkaido University, Sapporo, Hokkaido 060-0818, Japan \\ 4) Asahikawa Asahiyama Zoological Park and Wildlife Conservation Center, Asahikawa, Hokkaido 078-8205, Japan \\ 5) National Institute for Environmental Studies, Tsukuba, Ibaraki 305-8506, Japan
}

6) Office of Wildlife Management, Nature Conservation Bureau, Ministry of the Environment, Chiyoda-ku, Tokyo 100-8975, Japan

7) College of Bioresource Sciences, Nihon University, Fujisawa, Kanagawa 252-0880, Japan

\begin{abstract}
Currently in Japan, there is no established systemic approach for management of serious infectious diseases in wild animals, because it is not easy to monitor or control them, and they are often the exempts from existing laws and regulations. Under the circumstances, highly pathogenic avian influenza (HPAI) viruses were detected from wild birds in various regions in Japan during 2010. When the outbreak of HPAI in wild cranes was confirmed in Kagoshima prefecture, Japanese Society of Zoo and Wildlife Medicine (JSZWM) dispatched experts to the scene in response to a request from Ministry of the Environment. With the efforts of many members, JSZWM achieved solid results, but some problems were revealed at the same time. Here we provide the following five reports to examine our approach. 1) The progress and discussing the issue report of HPAI in swan and duck in Hokkaido (Yukiko Watanabe), 2) A status and countermeasure of the JSZWM on the occurrence of HPAI in Izumi, Kagoshima (Toshio Tsubota), 3) The progress and discussing the issue report of HPAI in crane in Kagoshima (Daisuke Fukui), 4) Avian influenza virus surveillance and researches by National Institute for Environmental Studies (Manabu Onuma), 5) How to cope with HPAI in wild birds by Ministry of the Environment? (Mai Yamamoto), Based on above reports, Koichi Murata, as the president of JSZWM, made the following recommendations to improve the management of infectious diseases in wild animals. He recommended 1) to arrange the related Acts that accompany with wildlife infectious diseases, 2) to make the collaboration and coordination among the ministries and agencies concerned with wildlife infectious diseases, 3) to set up the National Wildlife Health Center, 4) to create the early warning system for wildlife infectious diseases, 5) to create the network of research for wildlife infectious diseases, and 6) to improve the educational environment for wildlife infectious diseases.

Key words : management of infectious diseases in wild animals, infectious diseases surveillance and control system, ecological health, highly pathogenic avian influenza (HPAI)
\end{abstract}

Jpn. J. Zoo. Wildl. Med. 17 (2) : 33-42, 2012 
高見一利ほか

\section{はじめに}

野外の野生動物において重篤な感染症が確認された場合, 野 生動物は法規制の対象外であることが多く, 個体や群を人為的 に管理することが困難であることから, 国内では体系的な対策 法が確立されていない。そのようななか, 2010 年度に日本各 地で野鳥から高病原性鳥インフルエンザウイルスが確認され, 大きな問題となった。

日本野生動物医学会は, 2010 年 12 月に鹿児島県で野生の ツルから高病原性鳥インフルエンザウイルスが確認された際 に, 現地対応を正確かつスムーズに進めるために専門家の派遣 を行い, 環境省の主導する現場作業に貢献した。多くの学会員 の協力の下, 現場での検査業務において一定の成果をおさめ, 学会としての情報収集や体制構築の検討も進んだ。その一方で, 様々な課題や問題点も明らかとなった。

本稿は, 以下の 6 編の報告ならびに提言から成っている。

1. 北海道でのハクチョウその他の事例に関する経過と問題 点の報告（渡邊有希子）

2. 鹿児島県でのツルの事例に関する経過と本学会としての 対応 (坪田敏男)

3. 鹿児島県でのツルの事例に関する現地での対応と問題点 の報告（福井大祐）

4. 独立行政法人国立環境研究所における鳥インフルエンザ ウイルスの監視体制と関連研究について (大沼学)

5. 環境省における対応報告と今後の方針説明（山本麻衣）

6. 野生動物医学会に寄せられる期待と学会の方向性一学会 からの提言（村田浩一）

これらの報告ならびに提言によって, 2010 年度に実施され た高病原性鳥インフルエンザに対する一連の取組みにおいて実 施した活動を振り返るとともに, 今後どのような対応が求めら れるのかを考察する。

\section{1. 北海道でのハクチョウその他の事例に関する経過 と問題点}

2010 年 10 月に北海道稚内市の大沼にて採取されたカモの 糞から H5N1 型が確認された。12 月には, 九州・出水のナべ ヅルなど全国各地で飼育鳥または野鳥に高病原性鳥インフルエ ンザ（HPAI）の感染が次々と確認された。北海道でも警戒を 高めていたが, 2011 年 1 月下旬に浜中町および厚岸町の湖沼 でハクチョウやカモの HPAI 感染が発生した。

北海道で発生した HPAI 感染の対応を行った一員として, 今 後に資するべく経緯をまとめるとともに, 現在行われている簡 易検査に関する新たな発見や問題点などについて報告する。

\section{北海道における傷病鳥収容体制および感染対策}

北海道では, 希少種および国設鳥獣保護区内において保護 収容された傷病鳥獣は環境省が担当し, それ以外は北海道庁が 担当している。実際に収容された傷病鳥獣は, 環境省は所轄 の釧路湿原野生生物保護センター（ワイルドライフセンター： WLC）または動物園に治療などの対応を依頼し, 北海道庁は 各総合振興局内, または動物園や北海道獣医師会の指定動物病 院に対応を依頼している。猛禽類医学研究所は環境省の委託を 請け, WLC の傷病収容対応を担う他, 北海道獣医師会の指定 動物病院として総合振興局からの依頼による一般鳥種の治療対 応も行っている。

WLC では, 過去に HPAI 感染鳥を取り扱った経験と今回の 国内の発生状況を踏まえ, 施設内のバイオセキュリティの強化 に取り組んでいた。プレハブ式ユニットハウスを改良した隔離 収容施設の設置, 国立環境研究所の協力を得てトレーラーハウ スを改良し, LAMP (Loop-Mediated Isothermal Amplification) 法による遺伝子検査が可能な実験施設の設置や感染個体の生体 搬送を可能とするファンフィルターユニットを有する隔離輸送 ケージなどの準備に努めてきた。

今回ナベッ゙ルでの HPAI が初確認されたことは, 北海道に生 息する類縁種のタンチョウにとって艿威となる出来事であり, 給餌方法の見直し, 糞便調査など感染個体の早期発見の努力, 観光客やカメラマンなどの人の出入りに関する管理といった現 地で取るべき対応を関係機関で協議していた。しかし，ナベッ゙ ルをはじめ各所で発生した HPAI に関する臨床症状や現場での 問題・改善点などの具体的な情報が得られず, 事前に十分な体 制を構築できたとは言い難い。

\section{北海道での発生状況および浜中町，厚岸町における現地対応}

2011 年 1 月 18 日 13 時頃, 北海道釧路総合振興局から神 経症状を呈するオオハクチョウ成鳥を保護したとの一報を受け た。状況から HPAI 感染の可能性があり, 緊急性が高いと考え られたことから, 環境省にも同行を依頼し現地へ向かった。才 オハクチョウは段ボールに入れられ, 町役場の側に停車してい た軽トラックの荷台に置かれていた。人が近づいても座位のま ま逃げようとせず, 人が触るなどの強い外部刺激を加えること によってようやく立ち上がるが, 数歩でよろめき, 正常な歩行 はできなかった。頭部振戦を伴う重度の斜頸を認め, 特に頭部 は上下反転したままで正常な首の姿勢を保持できなかった。ま た重度の結膜炎を認めた（図 1）。現地で口腔内およびクロア カのスワブ採取を行い, 2 種類の簡易検査キット（エスプライ ン ${ }^{\circledR}$ インフルエンザ A\&B-N, ラピッドテスタ $\left.{ }^{\circledR} \mathrm{FLU}\right)$ 用いて 検査を実施したがいずれも陰性であった。隔離輸送ケージで WLC に搬送し, 簡易検査の再検査, LAMP 法による検査を実 施するが陰性であった。神経症状を呈するその他の疾患として 


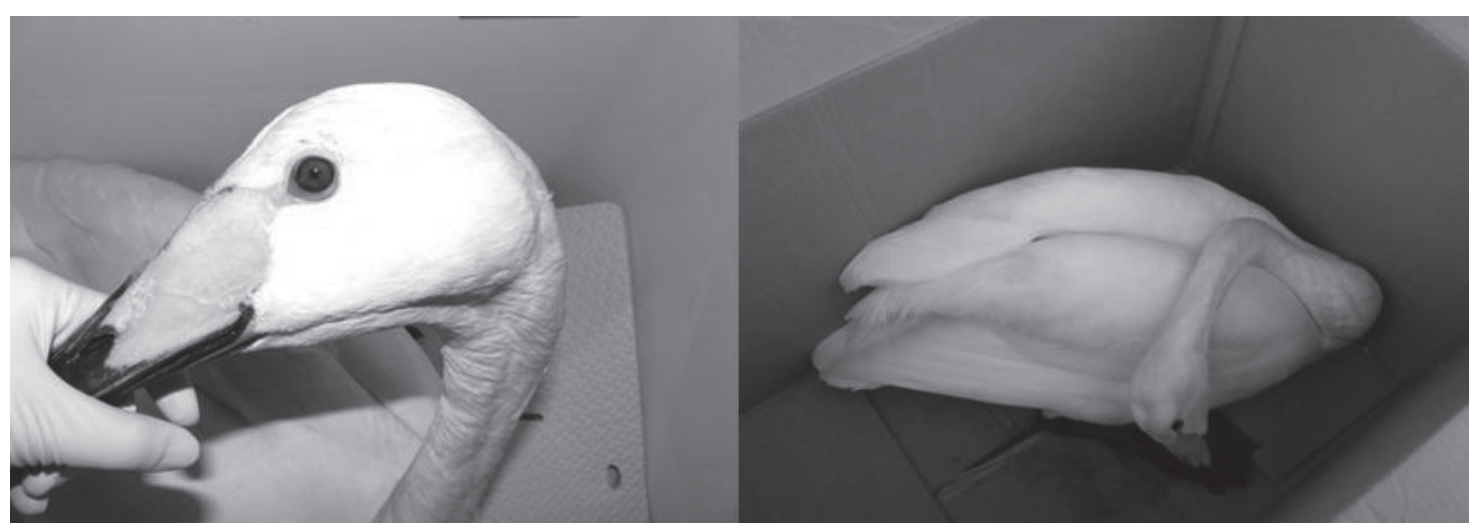

図 1 HPAI 陽性のオオハクチョウに認められた重度の神経症状および結膜炎

ウエストナイル熱や鉛中毒症に関する検査を実施したが陰性で あった。確定診断の結果が得られるまで, 隔離施設に収容し一 般状態の改善を主とした対症療法を施した。振興局は周辺のパ トロールを実施し，同日中にオナガガモなどの死体計 5 羽を 回収したが，いずれも食害がひどく検査はできなかった。

1 月 19 日に同じ場所で類似した神経症状を呈するオオハク チョウ幼鳥が保護された。頭部振戦を伴う重度の斜頸, 奇声, 歩行異常, 流涎, 水溶性下痢, 結膜炎の臨床症状が認められた。 簡易検査（エスプライン ${ }^{\circledR}$, ラピッドテスタ ${ }^{\circledR}$ ) で $\mathrm{A}$ 型陽性, LAMP 法でも A 型陽性を示したことから, 環境省判断により 安楽殺処分とした。収容地周辺では他にオナガガモなどの死体 計 4 羽が収容されたが，いずれも簡易検査は陰性であった。

18 日に収容したオオハクチョウ成鳥は確定診断で HPAI 陽 性と判明し, 安楽殺処分とした。現地では陽性個体を収容した 地点から $10 \mathrm{~km}$ 圈内を監視区域として設定し, 関係行政機関 で巡視を連日行った。監視区域内においては新たな衰弱個体の 収容は行わず, 陽性疑いとして全て安楽殺処分とした。発生地 域は, 北海道指定および国指定の鳥獣保護区が混在していたこ とから, 管轄と対応について混乱をきたしかねない状況であっ たが, 環境省, 北海道庁, 町役場, 漁業組合, 警察や開発局な どを含めた対策関係機関連絡会議を早くに設立することで柔軟 な対応と情報の共有を行うことができた。しかし冬季という時 期や環境的な障害により, 回収しきれない死体や先に捕食者に 食べられる死体も多かった。機材や人的資源の確保に当たって は金銭的な制約があったことも確かである。感染の拡大防止に は早期発見と回収が第一であり, 緊急時における迅速な体制の 構築と予算の確保の必要性を痛感した。

冬鳥の渡りシーズンが終了する春までに関係行政機関が生体 または死体回収した鳥類は 42 羽となった。うち水鳥 10 羽に H5N1 亜型が確定診断されたものの, 一部の感染鳥は簡易検査 キットで陰性を示した。しかし最初に生体収容されたオオハク
チョウに重度の結膜炎を認めたことから, 結膜スワブを簡易検 查に利用したところ, 口腔内やクロアカでは陰性または偽陽性 の場合も結膜スワブでは明瞭に陽性反応を認めたことが複数例 あった。これまで全国的に最初のスクリーニングとして行われ ている簡易検査は口腔内およびクロアカのスワブによるもので あるが, 絶対的でなく, 感染個体の見落としを少なくするため には検体の採取および検查方法の再考, そして臨床症状の観察 を併せた複合的な診断が必要であることが判明した。

\section{2. 鹿児島県でのツルの事例に関する経過と学会とし ての対応}

2010 年 12 月 21 ～ 27 日に 5 羽のナベッ゙ルから高病原性鳥 インフルエンザ (HPAI) ウイルスの感染が認められたことを 受け，本学会として次のような対応をとった。まず，本学会 に設置されている感染症対策委員会（福井大祐委員長）およ び国際交流委員会 (齋藤慶輔委員長) を空口として, 国内外の HPAI 発生の情報を入手した。これらの情報は, 随時学会メー リングリストを通じて会員に報告された。12月 24 日には, 会員からの提案もあり, 会長, 副会長および事務局長の 3 役で 学会としての対応について協議を開始した。12月 27 日, 環 境省担当者（本稿の執筆者の 1 人でもある山本麻衣さん）と 電話連絡を取り, 本学会への協力依頼を受けた。その具体的な 依頼内容としては, 現地 (出水) に獣医師である学会員 (専門家) を派遣・常駐して, ツルの死亡や衰弱などの状況を監視し, 必 要に応じて収容, 簡易検査ならびに安楽殺といった獣医学的業 務を行ってほしいとのことであった。この依頼に対して，3 役 で検討した結果, 出水への学会員 (獣医師) の専門家派遣を決 定した。環境省など外部との交渉を学会事務局 (坪田敏男) が 担当し, 学会内部の調整, 特に専門家派遣の調整を副会長（高 見一利）が担当した。12月 27 日, 高見副会長よりメーリン グリストを通じて, 会員に対して派遣専門家の募集が投げかけ 
高見一利ほか

られた。その結果，複数名の方より協力できる旨の返事をいた だいた。12月 29 日, 環境省「鳥インフルエンザなど野鳥対 策に係る専門家グループ会合」に村田浩一会長がオブザーバー として出席した。この席上でも本学会に対する期待が大きいこ とが示された。結局，2011 年 1 月 $2 \sim 6$ 日と 1 月 $6 \sim 17$ 日 に各々 1 名の学会員を現地派遣するに至った。派遣時には, 感 染症の専門家による現地業務に関する研修が実施された。

今回の出水への学会員 (専門家) 派遣を通じて課題として残つ たことを列挙しておく。

・学会内に感染症専門家チームを編成し, HPAI など感染症発 生時に迅速に派遣対応できるよう研修を含めて準備しておく。

・事前に担当省庁との連携を詰めておく。

・感染症発生時の連絡体制などフローチャートを作成してお <。

・派遣時の注意事項をガイドラインとして策定しておく。

・特に感染拡大の防止に対する対策は重要である。

・基金などを利用して予算支出について検討しておく。

\section{3. 鹿児島県でのツルの事例に関する現地での対応と 問題点}

ツルの集団渡来地の鹿児島県出水市に扔いて, 2010 年 12 月 $21 \sim 27$ 日にナベッ゙ル 5 羽の高病原性鳥インフルエンザ （HPAI）ウイルスの感染が確認された。現場では, 環境省から の派遣獣医師が緊急対応に就いていたが, 長期間に及ぶ対応 となり得ることが予想され, 日本野生動物医学会は, 2011 年 1 月 2 日〜 1 月 17 日に著者（福井大祐）を含む 2 名の会員を 現場派遣した。当学会による野生動物問題に対する実務対応と しては初めての取組みとなった。また, 国内で初めて野鳥の密 集地で経験する HPAI 発生事例となり，国策としての具体的対
応策が決められていなかったため, 生態学的健康と人道的支援 を目指し，試行錯誤しながらの対応となった。本編では，現地 での実務対応と現地で見えてきた課題について報告する。

著者は, 2011 年 1 月 $2 \sim 6$ 日, 出水市と阿久根市から出水 市出水ツル保護センターに搬入された死亡野鳥について，スワ ブ採取抽よび簡易キットによる HPAI 検查（簡易検查）に従事 した。

事前に, 環境省からの派遣獣医師より現地業務に関する研修 を受け，引き継ぎを行った後，任務に就いた。

「取り扱う全野鳥はHPAIウイルス陽性である」前提で対応 を行い, 感染因子の拡散防止に努めた。検查時には, 化学防護 服とグローブを二重，ゴーグル，N-95 マスクと長靴を着用し た（表 1）。また, 使用ごとに, 靴下とシャツ類は廃棄した。

野鳥の取扱いおよびスワブ採取は, 感染因子による周囲の污 染を防ぐため, 死体への直接的な接触は極力避け, ビニール袋 に包まれた状態で間接的に行った。また，スワブ採取の目的以 外の病理解剖など死体を直接取り扱う操作は一切行わないこ ととした。スワブは, 簡易検査用に加え, 精密検査（ウイルス 分離）および遺伝子検査用にそれぞれ気管とクロアカから各 1 本採取した（図2）。精密検査扔よび遺伝子検查用のスワブは, 冷蔵保管し，各専門機関に郵送された。

簡易検查は，直ちにインフルエンザウイルス抗原検出用試薬 （エスプライン ${ }^{\circledR} \mathrm{A} \& \mathrm{~B}-\mathrm{N}$, (㧣富士レビオ) を用いて行い, 結果 を判定した。

任務期間中, 取り扱った死亡野鳥は全 7 羽 (ヒドリガモ 1 羽, トビ 3 羽, アオサギ 1 羽, ナベヅル 1 羽, シロハラ 1 羽) で, 簡易検査の結果はすべて陰性であった。著者の後を引き継い だ別の当学会員が任務に従事した 1 月 $7 \sim 17$ 日に簡易検查を 行った野鳥は 15 羽で, 結果はすべて陰性であった。なお, 各

表 1 出水ツル保護センターに搬入された死亡野鳥の高病原性鳥インフルエンザ簡易検査時の服装と留意点

・簡易検查専用の衣服を準備し，作業後は現場に保管（最後に廃棄）

・その上に化学防護服を二重に着用

・ゴーグル，N-95 マスクを着用

・ラテックスグローブを履き, 袖口の周囲をガムテープで固定

・ラテックスグローブは，二〜三重履き（死体に触れた場合は，1 枚脱ぎ捨てて新たに着用）

・検査室に入る前に，専用の長靴に履き替え

・作業終了後, 検查室内でグローブと化学防護服 1 枚を外側に触れないように包みながら脱ぎ，処分

・ゴーグル, 手指と肌の露出部をアルコールで消毒

・長靴を消毒後, 退室

・私服に着替え, 靴下は廃棄

・帰る前に, 手指, 私靴などを消毒

・宿舎に戻った後, 手洗いとうがいの励行 


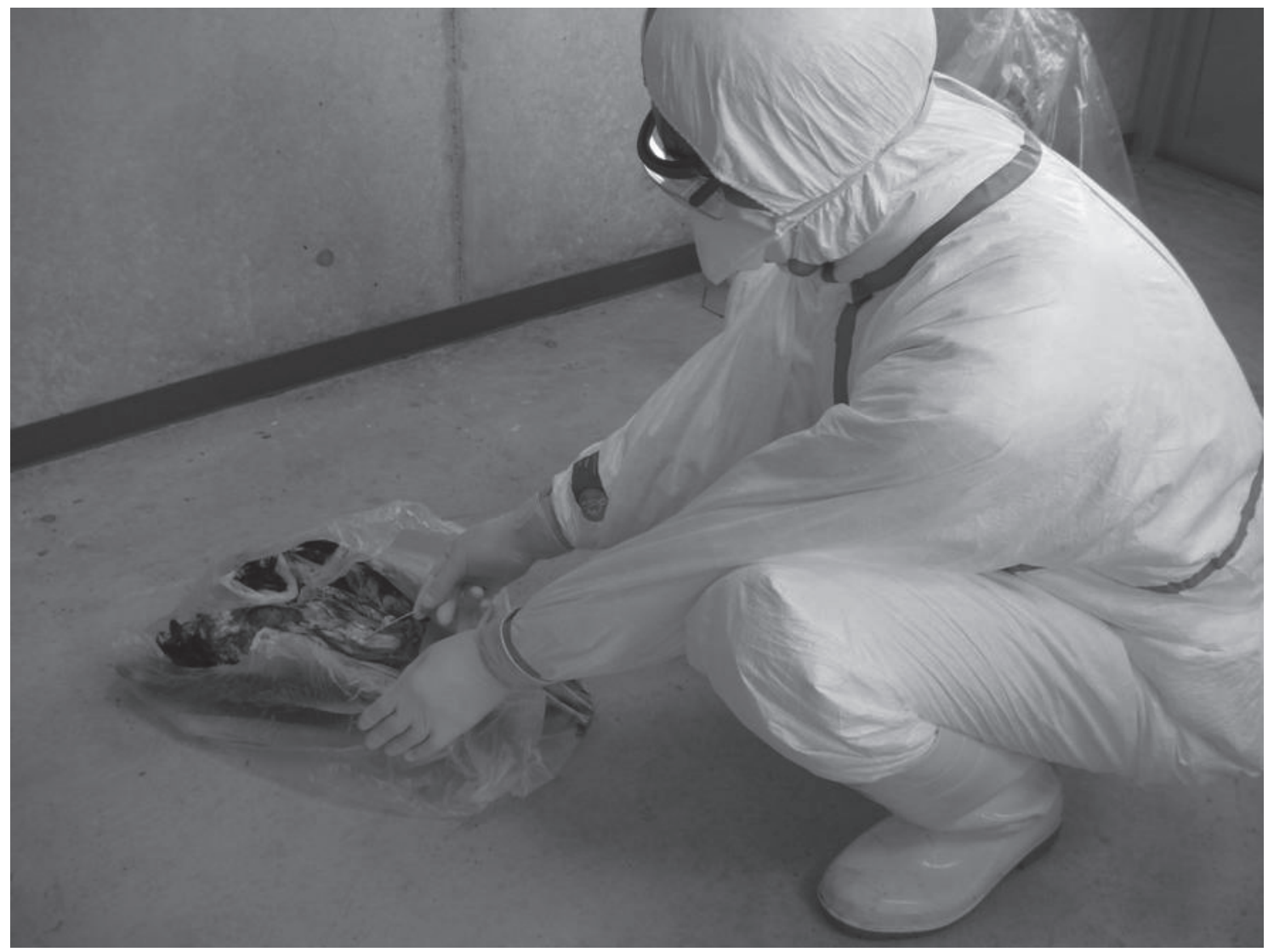

図 2 死亡野鳥からのクロアカスワブの採取

検体の（独）国立環境研究所で実施された遺伝子検査も陰性で あった。

著者は, 動物園で飼育展示動物の健康管理に従事する獣医師 で感染因子の持込みが許されない立場であったが，本任務が現 場での感染因子の周囲環境への拡散防止と自らへの感染防御が 絶対条件である以上, 専門家として行う各作業行程は他分野の 従事者であっても何ら変わりなく同じであった。任務終了後, 健康観察期間を 5 日間設け，11 日に職場復帰した。既述の通 り, 着衣の処理などより慎重かつ徹底した衛生管理を行うこと で, 絶対に失敗が許されない任務を完遂することができた。

未曾有の事態の中, 試行錯誤しながらの現場対応を通して見 えてきた課題もある。基本的に, P2 検査室の整備が理想であ るが, 出水市ツルセンターには検査のため隔離部屋を確保する ことができ, 現場対応としては十分機能させられていたと評価 できる。一方, 本対応には, 野鳥からの採材, 感染個体の取扱 い, 衛生および公衆衛生に習熟し, 感染因子の拡散を防止でき る技術を有する人材の確保が必要であり, 今後同様な事例発生 時に同等以上に機能させる体制の準備が課題として浮き彫りと なった。
このため, 当学会感染症対策委員会および保全医学専門家 チームは, 今後, 野生動物に関わる重要感染症対策のための同 様な緊急時対応が必要となった場合に, 迅速かつ効率的に各 種人道的支援が行えるように, 事前に「感染症対策専門家チー ム編成のための登録リスト」を作成して準備しておくことを提 案し, 第 49 回理事会で承認された。登録リストの作成後, 登 録者本人および環境省・当学会から所属先に協力体制について 事前に相互確認しておくことも必要である。また, 当学会員お よび各自治体で今後の有事に備えたシミュレーションや技術講 習会を実技研修, 学会誌, ニュースレター誌面, あるいはウェ ブサイト上などで実施する機会を増やしていくことも有用であ る。さらに, 環境省あるいは当学会で, HPAI 検査に必要な器 材を取りまとめたトランクキットを準備しておくとよいかもし れない。

今回の対応では, 生態学的健康を目指す当学会として野鳥の 感染症のモニタリングを通して 1 つの社会貢献のあり方を示 せたことは意義深い。第一に, 現地状況を科学的にリアルタイ ムで把握することにつながり, 今後の対策に役立てられた。第 二に，社会に正確な情報の迅速な普及に努めることで，風評 
被害の防止に役立てられた。第三に，今回の事例を通して環境 省九州地方環境事務所に獣医師が 1 名配属されることになり, 出水市のツル越冬地あるいは周辺環境において, 今後同様な野 生動物の感染症事例が発生したときに対応可能な体制が構築さ れたことは評価できる。

出水市は, 1 万羽を超える数のツル類が渡来する国際的に 重要な集団越冬地で, 給餉および保護区内に設けられた約 100haのねぐらのため密集して生息している。このように生 息域の減少や給餌・餌付けによって野鳥の個体群密度を増加さ せている地域は全国に多数あり，今後，生息地の再生や給餌・ 餌付けの自肃により個体群の健全な分散をより具体的に進めて いかねばならない。

今後, 野生動物の感染症および大量死に関する情報を共有す るためのネットワークの構築をさらに進め, 村田浩一当学会長 が提言する通り, 野生動物感染症早期警報システムの導入が早 急に求められている。

\section{4. 独立行政法人国立環境研究所における鳥インフル エンザウイルスの監視体制と関連研究について}

独立行政法人国立環境研究所（以下, 国環研）は野生動物 感染症モニタリング拠点を全国に2 か所設置している（図3）。 1 つは国環研内にある野生動物検疫施設である。本施設では国 環研に受け入れる絶滅危惧野生動物を対象に, オウム病（対象
動物：鳥類）, Q 熱（対象動物：哺乳類および鳥類）, ウエスト ナイル熱（対象動物：鳥類）, 高病原性鳥インフルエンザ（対 象動物：鳥類）, ブルセラ病（対象動物：哺乳類）, 野免病（対 象動物：哺乳類）およびレプトスピラ病（対象動物：哺乳類） の遺伝子検査を実施している。各病原体遺伝子はリアルタイム PCR 法（オウム病, Q熱ブルセラ病, 野兔病およびレプトス ピラ病）と LAMP 法（ウエストナイル熱执び高病原性鳥イ ンフルエンザ) で検出している。

\section{絶滅危惧鳥類種を対象とする鳥インフルエンザの監視体制}

国環研では 2004 年より絶滅危惧鳥類種を対象に鳥インフル エンザを継続して監視している。方法は現場における簡易検 查と研究所における遺伝子検査の 2 段階で実施している（図 4）。最初に絶滅危惧鳥類種の保護個体や死亡個体を対象に現 場において簡易検査を行う。その後, 検査用試料（保護個体 の場合はスワブ, 死亡個体の場合は個体全体）を国環研に移送 し, さらに LAMP 法（栄研化学(株) http://www.eiken.co.jp/）に よる遺伝子検査を実施している。2004 年から 2010 年までの 間にヤンバルクイナ（Gallirallus okinawae），タンチョウ（Grus japonensis），シマフクロウ（Ketupa blakistoni）など 40 種 998 個体を対象に鳥インフルエンザの検査を実施し全て陰性 であった。

\section{ガン・カモ類を対象とする鳥インフルエンザの監視体制}

国内で発生した高病原性鳥インフルエンザの感染経路につ

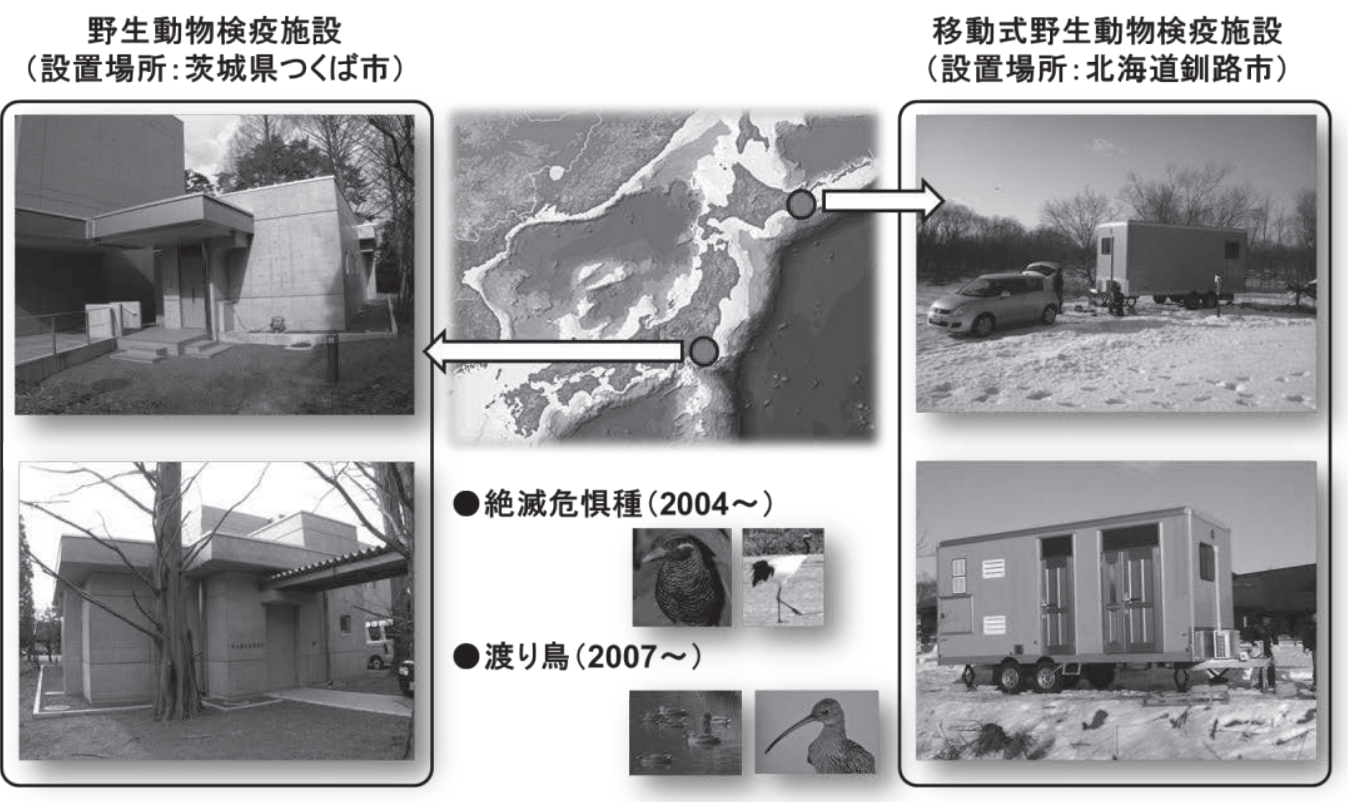

図 3 独立行政法人国立環境研究所における鳥インフルエンザ監視体制 全国に 2 か所検査拠点がある。 
診断キットを使用した現場での検査

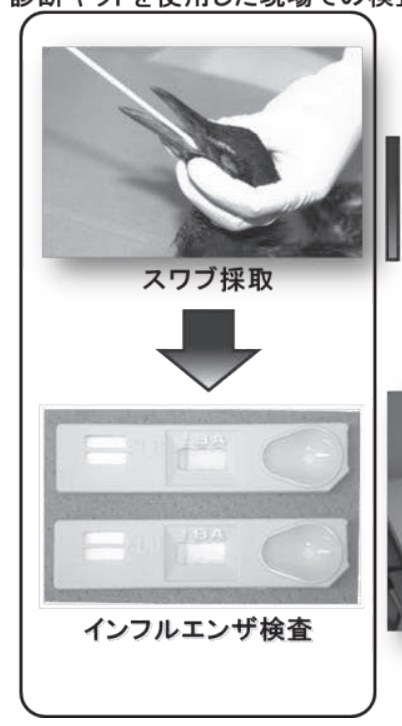

(独)国立環境研究所における検査

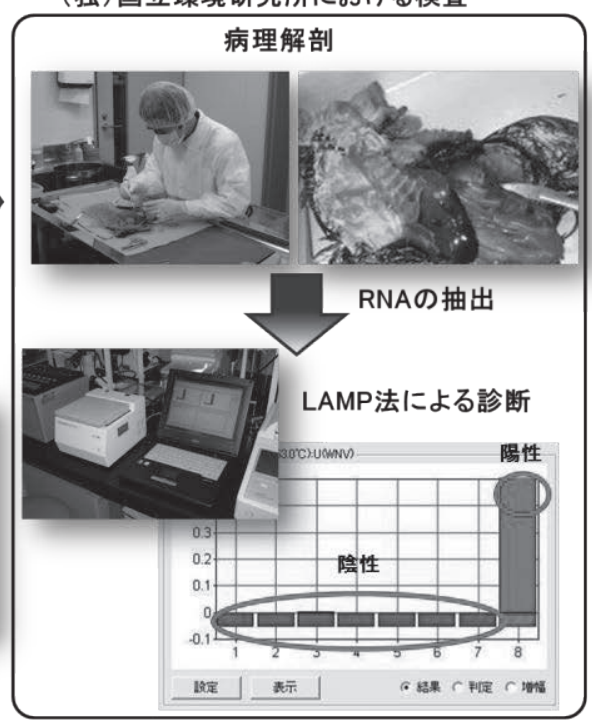

図 4 絶滅危惧鳥類における鳥インフルエンザ監視体制

いて，渡り鳥などの野生鳥類がウイルスの伝播に関わってい る可能性がある。環境省は全国にサンプリング地点を指定し, 2007 年度より継続して渡り鳥などの糞便サンプルにインフル エンザ A 型ウイルスが存在するのか遺伝子検查を実施してい る。これに加えて野生鳥類の死亡個体から気管スワブと総排泄 腔スワブを採取し，インフルエンザ A 型ウイルスを保有して いるのか遺伝子検査を行う体制も環境省は構築した（詳細につ いては「野鳥における高病原性鳥インフルエンザに係る対応技 術マニュアル」http://www.env.go.jp/nature/dobutsu/bird_f lu/manual/pref_0809.html を参照）。この体制の中で国環研は 遺伝子検査機関としても役割を担っている（図 5)。すなわち, 全国から検査用サンプル（ガン・カモ類の糞便および死亡野 鳥より採取したスワブ）を受け入れ, LAMP 法（栄研化学株式 会社 http://www.eiken.co.jp/) でインフルエンザ A 型ウイルス の有無を判定している（A型インフルエンザウイルス検出試薬 キット, 栄研化学株式会社)。これまでの受入れ状況は, 2007 年度 2,816 サンプル, 2008 年度 3,236 サンプル, 2009 年 度 3,174 サンプル, 2010 年度 7,886 サンプルである。特に 2010 年度は 16 道府県, 野生鳥類 60 個体より高病原性鳥イ ンフルエンザウイルスが分離されたことにより, 発生地域の追 加調査が実施されたことと死亡野鳥の検査依頼数が増加したこ とにより受入れ検体数が例年の約 2.5 倍となった。

\section{今後の予定}

2011 年 4 月より所内研究プロジェクト“人為的環境擋乱要 因の生物多様性影響評価と管理手法に関する研究”の一環とし

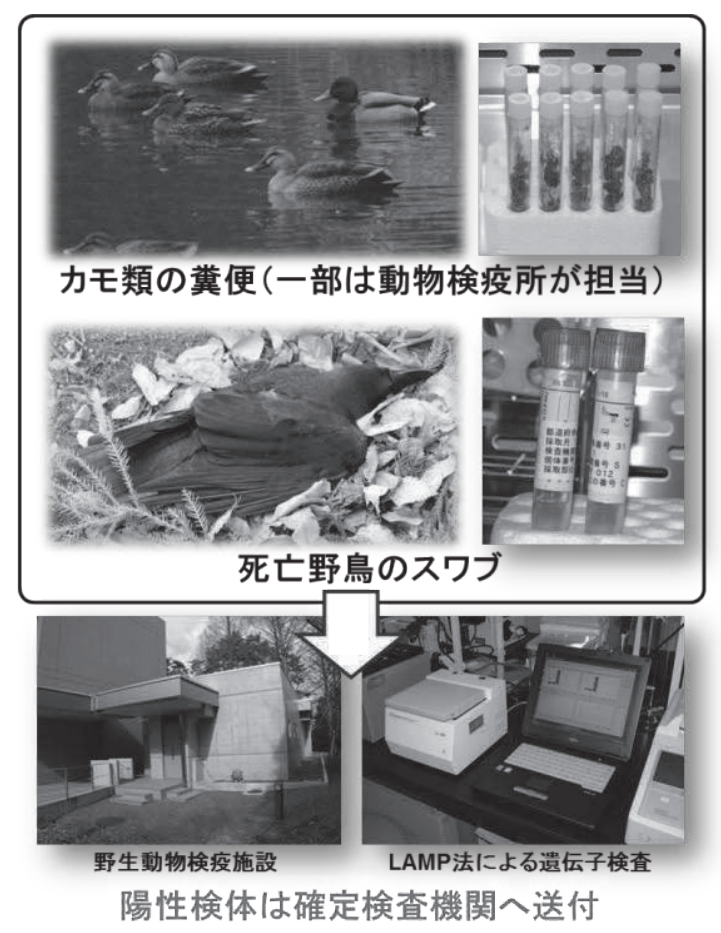

図 5 環境省が実施している鳥インフルエンザウイルスモニタ リングにおける独立行政法人国立環境研究所の役割 サンプルを野生動物検疫施設で受入れ，LAMP 法により 遺伝子検查を行う。 
高見一利ほか

て野鳥における高病原性鳥インフルエンザウイルスに関連する 研究を開始した。このプロジェクトにおける主な研究内容は1 鳥インフルエンザウイルスの国内への分布拡大プロセスに関す る研究, (2)高病原性鳥インフルエンザウイルスの野鳥への病原 性評価法開発である。

\section{5．環境省における対応報告と今後の方針}

\section{（1）野鳥における高病原性鳥インフルエンザへの対応の経緯}

野鳥における高病原性鳥インフルエンザへの対応は, 平成 16 年に高病原性鳥インフルエンザが発生した養䳕場近辺で, カラスでの感染が確認されたことに始まる。当時は, 家禽での 発生が先に起こるという前提で, 環境省が対応方針を作成した。 その後, 平成 20 年に, 周囲で家禽での発生がない中で十和田 湖などでハクチョウの感染が確認されたことを受けて, 渡り鳥 などの野鳥で先に感染が確認されることを想定し，「野鳥にお ける高病原性鳥インフルエンザにかかる都道府県鳥獣行政担当 部局などの対応技術マニュアル」を作成し, 環境省と都道府県 などが連携して対応に当たってきた。

平成 22-23 シーズン（10 月頃〜 5 月頃の冬鳥の渡りシーズ ンをいう。以下同じ。）に，過去にない大規模感染が確認され た際には，既存マニュアルでは十分といえない課題が明らかと なったため, 課題を総括して平成 23 年 9 月に同マニュアルの 改訂を行った。

\section{（2）平成 22-23 シーズンのウイルス保有状況の結果}

環境省では, 都道府県と協力し, 野鳥の高病原性鳥インフ ルエンザウイルスの保有状況調査を行っている。主に糞便を 採取するものと死亡野鳥からスワブ採取するものがあり，平 成 20 年にマニュアルを整備して以降の結果は以下表の通りで ある。平成 22-23 シーズンまでは, 原則として発生地周辺の 粪便採取を行った。ウイルス保有状況調査のフローは, 環境省 ホームページ (http://www.env.go.jp/nature/dobutsu/bird_flu/ index.html）にマニュアルを掲載しているので, 参照いただき たい。

表から分かる通り, 死亡野鳥 60 個体から高病原性鳥インフ ルエンザウイルスが検出された一方, 粪便からは検出されてい ない。ウイルスが検出された野鳥の鳥種などの情報は, 上記ホー ムページ参照。

また，それまでのシーズンと比較して，平成 22-23 シーズ ンは, 各地での発生地周辺での粪便採取や, 報道により一般の 関心が高まったことなどにより検体数が急増し（表 2），検査 機関が震災により被災した影響もあいまって, 検査の遅れが指 摘された。

\section{（3）平成 22-23 シーズンの結果から明らかになった課題}

(1)大規模飛来地での発生時対応

（2）のウイルス保有状況調査においては，ナベッ゙ル，マナ ヅルの越冬地（出水）, ハクチョウや力モ類の越冬地（中海・ 宍道湖）や中継地（厚岸湖周辺湖沼）での感染も確認された。

表 2 ウイルス保有状況調査 総括表

\begin{tabular}{llrrr}
\hline & \multicolumn{1}{c}{ 調査年 } & 20-21 年 & 21-22 年 & 22-23 年 \\
\hline & 検査総数 & 13,528 & 13,879 & 13,943 \\
\hline 定期糞便採取調査 & HPAI (H5N1) & 0 & 0 & 0 \\
& LPAI & 19 & 14 & 12 \\
& 検査総数 & $100^{* 1}$ & $130^{* 2}$ & 10,248 \\
\hline 発生時追加糞便 & HPAI (H5N1) & 0 & 0 & 0 \\
& LPAI & 0 & 0 & 25 \\
& 検査総数 & 517 & 185 & 5,591 \\
\hline 死亡野鳥等調査 & HPAI (H5N1) & 0 & 0 & 60 \\
& LPAI & 0 & 0 & 0 \\
& 検査総数 & $101 * 1$ & $100 * 2$ & $100 * 3$ \\
\hline 発生時捕獲調查 & HPAI (H5N1) & 0 & 0 & 0 \\
& LPAI & 0 & 0 & 0 \\
\hline
\end{tabular}

HPAI：高病原性鳥インフルエンザウイルス

LPAI：病原性の低い A 型インフルエンザウイルス

*1 : 十和田ハクチョウでの発生による調査

*2 : 愛知県豊橋市でのウズラでの低病原性 AI の発生による調査

*3 : 中海・宾道湖での発生による調査 
発生地での衰弱個体の保護収容の方法, 断続的に死亡野鳥が確 認される場合の検査体制の確保, 発生地周辺の通行車両の消毒 などについて，既存マニュアルでは十分な内容が含まれていな かったため, 各現場において, 随時専門家の意見を聞きながら 対応した。出水における対応については, 日本野生動物医学会 の協力もいただいた。

結果的には, それぞれの地域で爆発的な感染が起こることは なかったものの, 全国的な基本的な方針の整理, それぞれの生 息地などでの準備の必要性が明らかとなった。

(2)早期発見が可能となる体制などの整備

ウイルス侵入の早期発見のためには, 現場において効率的に 検査を行い, 環境省においても遺伝子検査などについて検体数 の急増に対応できるような体制の整備が必要である。

\section{（4）マニュアルの改訂などについて}

（3）の課題を踏まえ, 平成 23 年 9 月に, 警戒（対応）レベ ルとリスク種の見直し, 集団渡来地での対応の基本的な考え方 の追加, 定期糞便調査の時期の変更などを含む, マニュアルの 改訂を行った。

具体的には，早期発見，検査検体数の平準化などのため，野 鳥のリスク種を, 感受性や死体の発見のしやすさなどから 3 段階に分け，検査羽数を対応レベルに対応させた。リスク種 1 に分類された種については，通常時（発生していない段階）か ら死亡野鳥 1 羽から検査を行うことで早期発見を目指す一方, 平成 22-23 シーズンに死亡野鳥の半分以上を占めたカラス, サギ類についてはリスク種 3 に分類し, 検査の効率化のため, 複数羽の死亡野鳥が確認された際に検査を行うこととした。新 マニュアルの詳細については，環境省ホームページ参照。

なお，平成 23 年 4 月に交付された家畜伝染病予防法の改正 法において, 野鳥など家禽以外の鳥類で感染が確認された場合 にも, 必要に応じて消毒および通行制限・遮断を行うことや, 環境大臣と農林水産大臣の連携などが新たに規定された。家畜 衛生の観点でも, 野鳥などへの対応の必要性が法的に明示され たものである。

\section{(5) 最 後 に}

鳥インフルエンザをはじめとする野生鳥獣の感染症対策は, 国際的にも知見が十分でない分野であり，今後も，都道府県な どの地方公共団体や専門家と連携をはかり, 知見を集積しなが ら柔軟に対応していくこととしたい。併せて, 国際的な情報交 換が重要であることから，北東アジアを中心として専門家ネッ トワークを構築し, 情報共有をはかっていく。

\section{6. 野生動物医学会に寄せられる期待と学会の方向性 一学会からの提言}

国内においてロ蹄疫や高病原性鳥インフルエンザ（HPAI）
の感染が家畜や家禽で確認され，獣医学的のみならず社会的に も大きな問題となった。これらの感染症は, 野生動物も関与す る可能性があるため, 各方面から野生動物医学会の対応につい て質問や要望が寄せられた。その際に強く必要性を感じたのが, 野生動物感染症対策に打ける本学会の方向性を明確にし, 野 生動物感染症の監視と制御に役立つ体制整備を提案することで あった。

第 17 回日本野生動物医学会大会シンポジウムで，5名の演 者から提供された情報および参加者から寄せられた貴重な意見 を以下の 6 項目にまとめ, 本学会からの野生動物感染症対策 への提言としたい。

1. 野生動物感染症に関わる法律の整備

2. 野生動物感染症に関わる省庁間の連携

3. 野生動物感染症に関わる国立研究機関の設立

4. 野生動物感染症に関わる早期警報システムの構築

5. 野生動物感染症に関わる研究ネットワークの構築

6. 野生動物感染症に関わる教育環境の整備

最初に, 野生動物感染症に関わる法律の整備についてである が，現在，野生動物を公共財産と明記している国内法はない。 そのため, 野生動物の健康を維持することには何の法的根拠が ない。近い将来, そのための新法が制定されることも期待でき ない。しかし, 既存の法律を関連させ相補的に運用させれば, 野生動物感染症対策の法的根拠にできぬはずはないと考える。

次に関連省庁の連携であるが, 野生動物感染症に多少とも関 連する法律の所管省庁がパートナーシップを結べば，この分野 の対策が飛躍的に進展することは間違いない。具体的には, 野 生動物と家畜と人の健康をそれぞれ管轄する環境省, 農水省そ して厚労省の協働を期待したい。それが可能になれば, “One World, One Health（1 つの世界，1 つの健康）”の概念が衛生 行政に反映されることになる。2011 年 6 月に家畜伝染病予防 法が改正され, 家畜以外の動物, すなわち野生動物や人が関与 する家畜伝染病については， 3 省間の意見調整が求められてい ることから, 以前に比べると縦割りの壁は低くなりつつあるの かもしれない。

北米にある NWHC (National Wildlife Health Center) のよ うな野生動物衛生を研究する国立機関の設立は最も強く求めら れるところである（図 6)。その研究所で，さまざまな関連分 野の機関や団体が連携し情報や技術交流すれば, 希少種の保全, 野生動物と家畜の衛生, 公衆衛生と食の安全, そしてバイオセ キュリティを総合的かつ効率的に進めることができる。

野生動物感染症に関わるネットワークは, 野生動物の感染 症対策のみならず畜産業に多大な影響を与える家畜伝染病と 野生動物との相互関係の解明と感染拡大の予防に役立つもの である。そのために感染症情報ネットワークの構築をはかると 


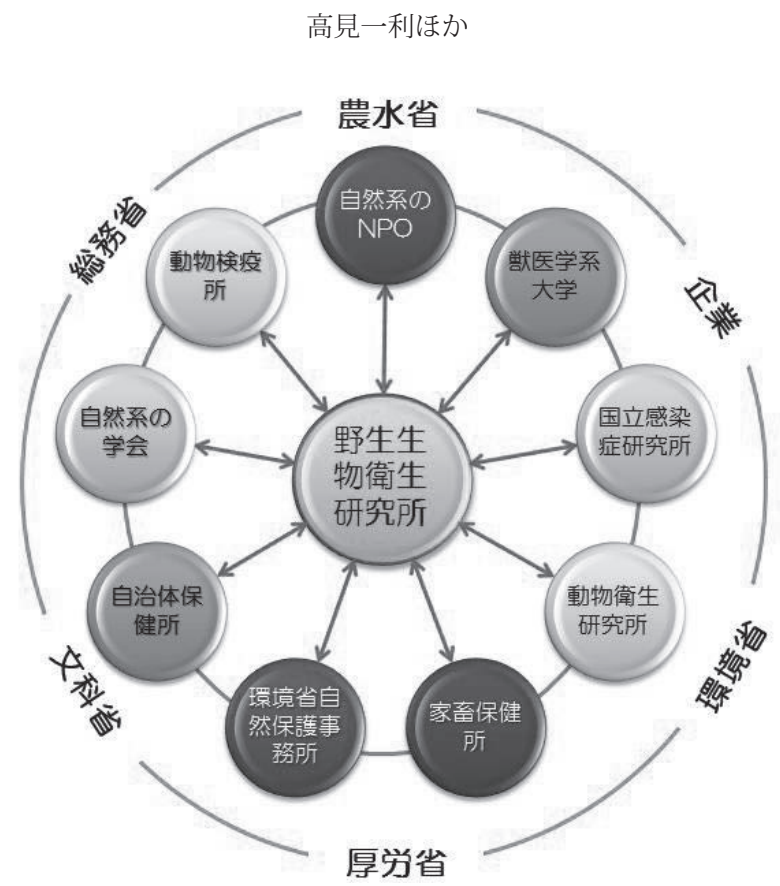

図 6 国立野生動物衛生研究所の概念図

ともに，国際地域連携の下で野生動物感染症早期警報システム (Early Warning System for Wildlife Diseases: EWSWD) の導入 を早急に検討する必要がある。また, 新規な診断法の開発, 野 生動物疫学手法の開発など, 包括的な動物衛生管理に活用可能 な各種技術開発に取り組む研究ネットワークの構築も大切であ る。さらに，それらの基盤づくりのためには，大学における野 生動物医学教育の環境整備が必須であると考える。

以上の提言は, 野生動物医学会の野生動物感染症に対する方 向性が, 保全医学に基づく家畜を含む動物と人と生態系の健康, すなわち生態学的健康（Ecological Health）の維持にあること を示すものである。

\section{要 約}

2010 年度に, 日本各地で野鳥から高病原性鳥インフルエン ザウイルスが確認され大きな問題となるなか, 発生地や調査研 究機関など各所で体制作りが進められた。日本野生動物医学会 も, 野生のツルへの感染が確認された鹿児島県に専門家の派遣
を行い現場作業に貢献した。これらの取り組みから一定の成果 が得られ, 情報収集や体制構築の検討も進んだ一方で, 様々な 課題や問題点も明らかとなった。一連の活動や検討を踏まえた 結果, 野生動物感染症対策を効果的に促進するためには, 感染 症の監視と制御に役立つ体制を構築することが必要であると考 えられた。従って, 本学会は体制整備として, 以下の取り組み を進めることを提言する。

1. 野生動物感染症に関わる法律の整備

2. 野生動物感染症に関わる省庁間の連携

3. 野生動物感染症に関わる国立研究機関の設立

4. 野生動物感染症に関わる早期警報システムの構築

5. 野生動物感染症に関わる研究ネットワークの構築

6. 野生動物感染症に関わる教育環境の整備

この提言は, 本学会の野生動物感染症に対する方向性が, 生態 学的健康の維持にあることを示すものである。

キーワード：野生動物感染症管理, 感染症監視制御体制, 生 態学的健康, 高病原性鳥インフルエンザ 